\title{
A chromosome map of the Flavescence dorée phytoplasma
}

\author{
Sylvie Malembic-Maher, ${ }^{1,2} \dagger$ Fiona Constable, ${ }^{3,4,5}+\ddagger$ Agnès Cimerman, ${ }^{1,2}$ \\ Guillaume Arnaud, ${ }^{1,2}$ Patricia Carle, ${ }^{1,2}$ Xavier Foissac ${ }^{1,2}$ \\ and Elisabeth Boudon-Padieu $3,4,5$
}

Correspondence

Sylvie Malembic-Maher

smalembi@bordeaux.inra.fr

Received 8 October 2007

Revised 7 February 2008

Accepted 23 February 2008

\author{
'INRA, UMR1090 Génomique Diversité Pouvoir Pathogène, F-33883 Villenave d'Ornon, France \\ ${ }^{2}$ Université Bordeaux 2, UMR1090 Génomique Diversité Pouvoir Pathogène, F-33076 Bordeaux, \\ France \\ ${ }^{3}$ INRA, UMR1088 Plante Microbe Environnement, F-21065 Dijon, France \\ ${ }^{4}$ Université de Bourgogne, UMR1088 Plante Microbe Environnement, F-21000 Dijon, France \\ ${ }^{5}$ CNRS, UMR1088 Plante Microbe Environnement, F-21000 Dijon, France
}

\section{INTRODUCTION}

Phytoplasmas are plant-pathogenic bacteria belonging to the class Mollicutes, a group of wall-less organisms phylogenetically related to low G+C content Grampositive bacteria (Weisburg et al., 1989). Phytoplasmas are associated with several hundreds of plant diseases that damage annual and perennial crops, including fruit trees and grapevines (Lee et al., 2000; Seemüller et al., 2002). These pathogens multiply within the phloem cells of the host plant and are transmitted from plant to plant by phloem-feeding insects (Christensen et al., 2005; Weintraub \& Beanland, 2006). The failure of numerous attempts to cultivate phytoplasmas in cell-free medium has hindered progress in their study. The development of molecular tools has enabled identification and preliminary

†These authors contributed equally to this paper.

$\ddagger$ Present address: Department of Primary Industries, Knoxfield, Private Bag 15, Ferntree Gully Delivery Centre, Victoria 3156, Australia.

Abbreviations: FD, Flavescence dorée; FD-P, Flavescence dorée phytoplasma; $\mathrm{SSH}$, subtractive suppression hybridization. classification of phytoplasmas according to 16S rDNA gene phylogeny and RFLP profiling into 14 groups (Lee et al., 2000). Several phytoplasmas have been assigned Candidatus status (IRPCM Phytoplasma/Spiroplasma Working Team Phytoplasma taxonomy group, 2004; Lee et al., 2000; Seemüller et al., 2002). Whereas important progress has been made in phytoplasma classification and ecology, little is known about molecular determinants of phytopathogenicity and insect vector specificity. These areas should benefit from comparative analyses of phytoplasma genomes. The size of several phytoplasma chromosomes has been determined by PFGE, and ranges from 530 to $1350 \mathrm{kbp}$, revealing an important heterogeneity within and between phylogenetic groups that does not correlate with the phylogenetic classification (Marcone et al., 1999; Neimark \& Kirkpatrick, 1993). Physical and genetic maps of phytoplasma chromosomes have been determined for 'Candidatus Phytoplasma pruni' (Firrao et al., 1996), sweet potato little leaf phytoplasma (Padovan et al., 2000), 'Candidatus Phytoplasma mali' (Lauer \& Seemüller, 2000) and 'Candidatus Phytoplasma prunorum' (Marcone \& Seemüller, 2001). Phytoplasma genomes have been partly 
sequenced for 'Candidatus Phytoplasma pruni' (Liefting \& Kirkpatrick, 2003) and 'Candidatus Phytoplasma solani' (Cimerman et al., 2006), and the complete genome sequences of two strains of 'Candidatus Phytoplasma asteris' (860 and $706 \mathrm{kbp}$ ) have been described (Bai et al., 2006; Oshima et al., 2004).

Flavescence dorée (FD) is an epidemic, leafhoppertransmitted, quarantine disease of grapevines which has an important economic impact in Europe (BoudonPadieu, 2002). This pathogen belongs to the $16 \mathrm{SrV}$ group, for which the genome of 'Candidatus P. asteris' (16SrI group) can hardly serve as a reference due to the important phylogenetic distance between these two groups (Lee et al., 2004a, b; Oshima et al., 2004).

This paper describes the physical map of the FD phytoplasma (FD-P) chromosome as a preliminary step of a genome project. As phytoplasmas are not available in culture, the first step was to isolate phytoplasma DNA from plant extracts as described by Padovan et al. (2000). We constructed an FD92 strain chromosome map, employing restriction endonucleases with $\mathrm{G}+\mathrm{C}$-rich recognition sequences that produce a limited number of large restriction fragments from the AT-rich chromosomal DNA. Following the separation and the sizing of the restriction fragments under appropriate conditions, the fragments were separated by PFGE and organized along the circular chromosome by performing double digestion and Southern hybridization.

\section{METHODS}

Phytoplasma source and plant material. Phytoplasma strains FD70 and FD92 were transmitted to broad bean (Vicia faba var. Aquadulce) (Caudwell et al., 1970) using Scaphoideus titanus leafhoppers collected in FD-affected vineyards in the south-west of France in 1970 and 1992, respectively. FD92 has been maintained since this time by uninterrupted serial transmission from broad bean to broad bean using Euscelidius variegatus as an alternative leafhopper vector (Caudwell et al., 1972). FD70 and FD92 were also transmitted by infected E. variegatus to periwinkle (Catharantus roseus) and maintained by grafting (Caudwell et al., 1973). FD70 and FD92 belong to types FD1 and FD2 of FD-P, respectively, as defined by Arnaud et al. (2007).

Nucleic acids extraction and preparation of phytoplasma chromosomes. Total nucleic acids were extracted from $1 \mathrm{~g}$ leaf midribs from broad bean or periwinkle plants by the CTAB method, according to Maixner et al. (1995). The resulting nucleic acid pellets were resuspended in $60 \mu \mathrm{l} 1 \times \mathrm{TE}(10 \mathrm{mM}$ Tris/HCl, $1 \mathrm{mM}$ EDTA, $\mathrm{pH} 8)$.

Phytoplasma chromosomes were prepared according to the method of Padovan et al. (2000). Two grams of fresh midribs, petioles and stems from the top $15 \mathrm{~cm}$ of FD92-infected broad beans were ground at $4{ }^{\circ} \mathrm{C}$ in polyethylene bags with a ball-crushing apparatus (Bioreba) in $12 \mathrm{ml}$ ice-cold extraction buffer $\left[0.1 \mathrm{M} \mathrm{Na} \mathrm{HPO}_{4}, 0.03 \mathrm{M}\right.$ $\mathrm{NaH}_{2} \mathrm{PO}_{4}, 10 \%(\mathrm{w} / \mathrm{v})$ sucrose, $2 \%(\mathrm{w} / \mathrm{v})$ polyvinylpyrrolidone (MW 40000 ), $10 \mathrm{mM}$ EDTA, pH 7.6, with $0.15 \%$ (w/v) BSA and $1 \mathrm{mM}$ isoascorbic acid] and then subjected to different centrifugation and filtration steps, as described by Padovan et al. (2000), to obtain $50 \mu \mathrm{l}$ of a final phytoplasma suspension in TSE buffer [20 mM Tris/
$\mathrm{HCl}, 10 \%$ (w/v) sucrose, $0.05 \mathrm{M} \mathrm{EDTA}, \mathrm{pH}$ 8]. The suspension was mixed at $55{ }^{\circ} \mathrm{C}$ with an equal volume of molten $2 \%$ (w/v) LMP agarose (Bio-Rad) dissolved in $2 \times$ TES buffer $(0.2 \mathrm{M}$ Tris/HCl, $0.2 \mathrm{M}$ $\mathrm{NaCl}, 20 \mathrm{mM}$ EDTA, $\mathrm{pH} 8$ ) and was poured into $100 \mu \mathrm{l}$ rectangular plastic moulds. The resulting agarose blocks were treated for $60 \mathrm{~h}$ at $50{ }^{\circ} \mathrm{C}$ in lysis buffer with four buffer changes [1\% (w/v) N-lauroyl sarcosine, $500 \mathrm{mM}$ EDTA, $1 \mathrm{mg}$ proteinase $\mathrm{K} \mathrm{ml}^{-1}$ ]. Blocks were washed for $12 \mathrm{~h}$ in lysis buffer without proteinase $\mathrm{K}$ and stored at $4{ }^{\circ} \mathrm{C}$ in $0.5 \mathrm{M}$ EDTA, $\mathrm{pH}$. The same procedure was executed with healthy broad beans as a control.

Restriction endonuclease digestion and PFGE. Endonuclease digestion was carried out in agarose blocks. After two rinses with 10 vols $1 \times \mathrm{TE}$, the blocks were incubated overnight at $4{ }^{\circ} \mathrm{C}$ in $10 \mathrm{vols}$ $1 \times$ TE plus $1 \mathrm{mM}$ PMSF to inactivate the proteinase $\mathrm{K}$, then rinsed four times for $2 \mathrm{~h}$ at $4{ }^{\circ} \mathrm{C}$ with 10 vols $1 \times$ TE. Blocks were first incubated for $1 \mathrm{~h}$ at $4{ }^{\circ} \mathrm{C}$ in 5 vols digestion buffer [4 mM DTT, $0.1 \mathrm{mg} \mathrm{BSA} \mathrm{ml}{ }^{-1}, 4 \mathrm{mM}$ spermidine, $1 \times$ restriction enzyme buffer supplied by the manufacturer (Euromedex)], then transferred to 2 vols digestion buffer plus 30 units restriction enzyme (Euromedex) and left overnight at the recommended temperature. For double digestions, the first enzyme was inactivated by incubating the blocks for $2 \mathrm{~h}$ at $4{ }^{\circ} \mathrm{C}$ in 10 vols $0.5 \mathrm{M}$ EDTA, $\mathrm{pH} 8$ followed by three rinses, and the digestion procedure was repeated with the second enzyme. Rare-cutting restriction endonucleases ApaI, BssHII, EagI, I-CeuI, KpnI, MluI, PvuII, SalI, SmaI and XhoI were selected on the basis of the length and $\mathrm{G}+\mathrm{C}$ content of their recognition sequence to generate a small number of fragments suitable for restriction mapping by PFGE. All single and double restriction digestions were performed separately and to completion.

For the identification of DNA fragments smaller than $10 \mathrm{kbp}, 5 \mu \mathrm{g}$ DNA extracted from FD92-infected broad beans by the CTAB method were also digested overnight at the recommended temperature with 20 units restriction enzyme in a final volume of $40 \mu$ l.

PFGE was performed by the clamped homogeneous electrical field (CHEF) technique using the CHEF-DR III system (Bio-Rad). Blocks were installed in a $0.8 \%(\mathrm{w} / \mathrm{v})$ pulsed field certified agarose (Bio-Rad) gel. Electrophoresis was performed in $0.5 \times \mathrm{TBE}(44.5 \mathrm{mM}$ Tris, $44.5 \mathrm{mM}$ boric acid, $1 \mathrm{mM}$ EDTA, pH 8.3$)$ at $6 \mathrm{~V} \mathrm{~cm}^{-1}$ and $14{ }^{\circ} \mathrm{C}$ at an angle of $120^{\circ}$ for $18 \mathrm{~h}$, and with various ramped pulse times: $0.7-$ $13 \mathrm{~s}$ for low-size-range resolution, $2-40 \mathrm{~s}$ and $2-60 \mathrm{~s}$ for mediumsize-range resolution, and 5-90 s for high-size-range resolution.

Gels were stained with ethidium bromide $\left(2 \mu \mathrm{g} \mathrm{ml}^{-1}\right)$ and destained by washing for $1 \mathrm{~h}$ in distilled water before visualization under UV light. The molecular mass of fragments was estimated by comparison to yeast chromosome PFG (Saccharomyces cerevisiae YPH80) and lowrange PFG (mixture of $\lambda$ DNA HindIII fragments and concatemers) markers from New England Biolabs using Quantity One 4-2-3 software (Bio-Rad). The mean size of each fragment was calculated from at least three different gels.

Isolation and characterization of FD-P DNA fragments used as genetic markers. DNA fragments used for the realization of the genetic map are described in Table 1. FD2 and FD9 ( $\sec Y$ gene) fragments were obtained from infected broad beans by cloning FD-Penriched DNA fractions isolated from bisbenzimide-CsCl density gradients as described previously (Daire et al., 1992, 1997). Their sequence was extended by genome walking using the Genomewalker kit (Clontech), as described by Arnaud et al. (2007). In this way, the map gene was characterized downstream of the $\sec Y$ gene (Arnaud et al., 2007). The FDSH05 and FDDH29 fragments were obtained by subtractive suppression hybridization (SSH) and double-SSH, respectively, between HincII-digested DNA from infected and healthy periwinkle as described by Cimerman et al. (2006). uvrB-degV was obtained by SSH and genome walking as described by Arnaud et al. 
Table 1. List of probes used for the establishment of the FD-P genetic map

\begin{tabular}{|c|c|c|c|c|}
\hline Probe name & Sequence origin & Product & Accession no. & Reference \\
\hline map & FD70-infected C. roseus & Methionine aminopeptidase & AM238512 & Arnaud et al. (2007) \\
\hline$u v r B-\operatorname{deg} V$ & FD70-infected C. roseus & $\begin{array}{l}\text { Subunit B of excinuclease ABC-DegV family } \\
\text { protein }\end{array}$ & AM238511 & Arnaud et al. (2007) \\
\hline \multirow[t]{2}{*}{ FD9 $(\sec Y)$} & FD92-infected $V \cdot f a b a$ & Preprotein translocase $\operatorname{Sec} Y$ & AF458384 & $\begin{array}{l}\text { Daire et al. (1992); Angelini et al. } \\
\text { (2003) }\end{array}$ \\
\hline & FD70-infected C. roseus & & AM238512 & Arnaud et al. (2007) \\
\hline FD2 & FD70-infected C. roseus & ABC-transporter ATP-binding protein & Not in databases & Daire et al. (1992) \\
\hline FDDH29 & FD70-infected C. roseus & $\begin{array}{l}\text { Similarity with hypothetical protein from aster } \\
\text { yellows witches' broom phytoplasma YP } 456430\end{array}$ & AM889025 & Arnaud (2006) \\
\hline FDSH05 & FD70-infected C. roseus & No homology in databases & AM889026 & Arnaud (2006) \\
\hline tuf & FD92-infected $V . f a b a$ & Elongation factor EF-Tu & AM939565 & Unpublished genome survey \\
\hline $16 \mathrm{~S}$ rDNA & FD70-infected C. roseus & 16S RNA & $\mathrm{X76560}$ & Seemüller et al. (1994) \\
\hline
\end{tabular}

(2007). The tuf gene was obtained from an unpublished genome survey of strain FD92 propagated in broad bean.

Southern hybridization. After depurination, denaturation and neutralization, DNA fragments from electrophoresis gels were submitted to capillary transfer onto a nylon membrane (Nytran Super Charge; Schleicher and Schuell) under neutral conditions, according to standard procedures (Sambrook et al., 1989). Labelled DNA fragments used for Southern hybridization are described in Table 1 and PCR primers and DNA sources used for their synthesis are described in Table 2. Each probe except $\sec Y$ was labelled with digoxigenin by nested-PCR amplification. The first amplification was performed on $1 \mu$ l of either diluted DNA from phytoplasma-infected plant or purified recombinant pGEM-T Easy plasmid (Promega) containing the FD-P DNA insert in a volume of $25 \mu \mathrm{l}$ with $1 \mu \mathrm{M}$ each PCR primer, $2 \mathrm{mM} \mathrm{MgCl}_{2}, 200 \mu \mathrm{M}$ dNTPs and 0.04 units Taq polymerase $\mu \mathrm{l}^{-1}$ (Promega). Nested PCR was performed on $1 \mu \mathrm{l}$ of a $1 / 100$ dilution of the first PCR product, in a volume of $50 \mu \mathrm{l}$ with $20 \mu \mathrm{M}$ digoxigenin-dUTP (DIG-11-dUTP alkali-labile; Roche). PCR conditions are detailed in Table 2. The FD9 $(\sec Y)$ fragment was labelled with $\left[\alpha^{-}{ }^{32} \mathrm{P}\right] \mathrm{dATP}$ using the DNA Labelling System or Nick Translation System (Invitrogen), according to the manufacturer's instructions. Probes were purified using ProbeQuant G-50 micro columns (Amersham Biosciences), according to the manufacturer's instructions. The blotted membranes were pre-hybridized for $1.5 \mathrm{~h}$ and then overnight at $37{ }^{\circ} \mathrm{C}$ in hybridization solution $[50 \%(\mathrm{v} / \mathrm{v})$ formamide, $5 \times$ SSC, $2 \%(\mathrm{w} / \mathrm{v})$ blocking reagent (Roche), $0.1 \%(\mathrm{w} / \mathrm{v})$ $N$-lauroyl sarcosine, $0.02 \%(\mathrm{w} / \mathrm{v})$ SDS and $200 \mu \mathrm{g}$ heat-denatured salmon sperm DNA ml ${ }^{-1}$ (Stratagene)] and hybridized with $20 \mathrm{ng}$ purified labelled probes $\mathrm{ml}^{-1}$. Membranes were then washed four times for $15 \mathrm{~min}$ each in $2 \times \mathrm{SSC} / 0.5 \%(\mathrm{w} / \mathrm{v}) \mathrm{SDS}$ at ambient temperature and twice for $30 \mathrm{~min}$ each in $0.1 \times \mathrm{SSC} / 0.1 \%(\mathrm{w} / \mathrm{v})$ SDS at $50{ }^{\circ} \mathrm{C}$. Probe hybridization was revealed using anti-digoxigenin FAb fragment and CDP-Star as substrate, according to the Dig DNA Labelling and Detection kit (Roche).

\section{RESULTS}

\section{Separation of FD-P chromosome and restriction fragments resulting from single and double digestions}

As shown in Fig. 1, PFGE performed with undigested DNA prepared from FD92-infected broad beans revealed a fragment around $680 \mathrm{kbp}$ (lanes 1 and 2). No fragment was detected with DNA prepared from control healthy broad beans (lane 3 ).

Chromosomal DNA of strain FD92 was digested individually with 10 different restriction enzymes possessing $\mathrm{G}+\mathrm{C}-$ rich recognition sequences. Enzymes I-CeuI and $K p n I$ did not digest the phytoplasma chromosome, and XhoI, PvuII, $A p a \mathrm{I}$ and SmaI were not selected to construct the physical map as they produced only small or too many fragments, or gave smeary banding patterns (not shown). However, BssHII, EagI, MluI and SalI all generated a clear banding pattern with two or three fragments between 50 and $550 \mathrm{kbp}$ and were consequently selected for mapping. No fragments with sizes larger than $50 \mathrm{kbp}$ were observed with DNA prepared from healthy broad beans (Fig. 2a, lanes 12 and 13). Single restriction profiles are shown in Fig. 2(a, b), lanes 1-4. Mean sizes of fragments were determined from at least three independent PFGE experiments with running conditions optimized to resolution of low-, medium- or high-size-range, depending on the expected size of the fragments. These profiles are presented in Table 3. PFGE analysis revealed two fragments of $415.1 \pm 8.2$ and $193 \pm 6.4 \mathrm{kbp}$ for Sall digestions (lanes 1), two fragments of $552.1 \pm 8.4$ and $110.2 \pm 2.7 \mathrm{kbp}$ for BssHII digestions (lanes 2), three fragments of $404.9 \pm 5.1,146.6 \pm 6.5$ and $109 \pm 3.1 \mathrm{kbp}$ for EagI digestions (lanes 3) and three fragments of $515.6 \pm 6.4,80.1 \pm 6.6$ and $73.2 \pm 6.2 \mathrm{kbp}$ for MluI digestions (lanes 4). As shown in Fig. 2(a, b), BssHII, EagI, MluI and SalI digestions of strain FD92 DNA also produced fragments smaller than $50 \mathrm{kbp}$. Their identification and size determination were not easy to perform because of a background signal also present in healthy broad bean controls which might correspond to broad bean chloroplast or mitochondrial DNA contaminating the phytoplasma chromosome preparations. Therefore, fragments smaller than $50 \mathrm{kbp}$ were identified by hybridization with FD-specific probes.

BssHII/SalI, EagI/SalI, MluI/SalI, EagI/BssHII, MluI/BssHII and MluI/EagI double digestions generated three, four, three, three, four and five fragments longer than $50 \mathrm{kbp}$, respectively (Fig. $2 \mathrm{a}$ and $\mathrm{b}$, lanes $5-10$ ). Their mean sizes 
Table 2. List of primers and PCR conditions employed for the synthesis of probes used for mapping

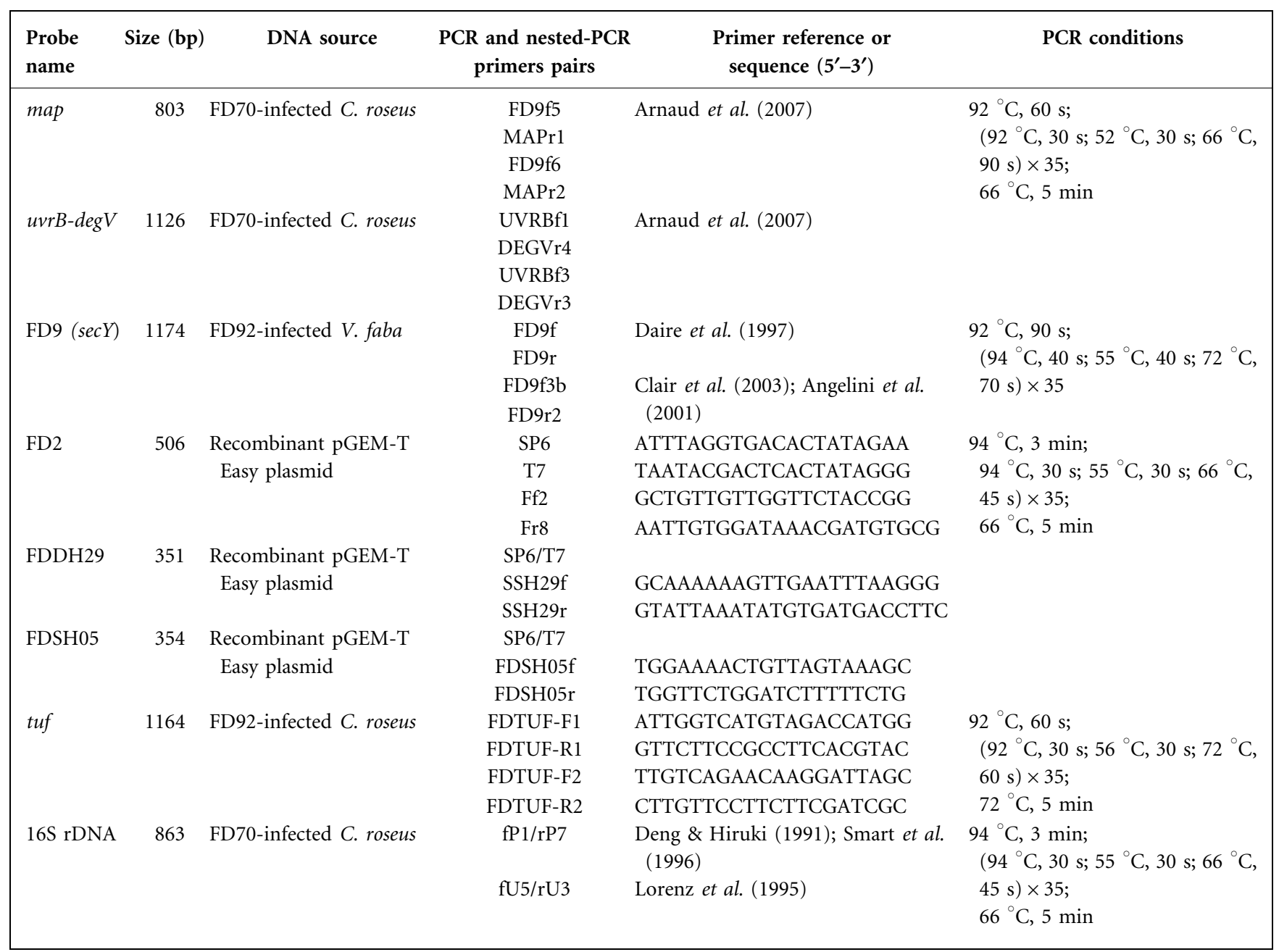

were determined from at least three independent PFGE experiments and are presented in Table 3. As for the single digestions, fragments smaller than $50 \mathrm{kbp}$ were confirmed by hybridization.

\section{Hybridization profiles of the genetic markers}

Hybridization profiles of the different genetic markers are presented Fig. 2(c, d, e, f, g, h, i). The mean sizes of fragments are presented in Table 3 . Hybridizations using probes FDSH05 (Fig. 2d, lanes 1-10), FDDH29 (Fig. 2e and $\mathrm{h}$, lanes 1-10), map (Fig. 2f, lanes 1-10), uvrB-degV (Fig. 2 g, lanes 1-10) and tuf (Fig. 2h, lanes 1-10) each revealed a single fragment. No fragments were revealed following hybridization to healthy control DNA (lanes 12 and 13). This indicated that these markers were present in a single copy on the strain FD92 chromosome. As expected, hybridization with the $\sec Y$ gene to BssHII, MluI, SalI BssHII/SalI, MluI/SalI and MluI/BssHII restriction fragments (data not shown) presented the same profile as hybridization with the map gene which is already known from sequence data to be located next to the $\sec Y$ gene
(Arnaud et al., 2007; Arnaud, 2006). Hybridization to EagI, EagI/SalI, EagI/BssHII and MluI/EagI restriction fragments was not performed. Hybridization with the FD2 fragment (data not shown) also produced the same profile, showing that this marker is located on the same restriction fragment. The FDDH29 probe gave the same hybridization profile as the tuf gene, showing that both markers are located on the same restriction fragment. Hybridization performed with the $16 \mathrm{~S}$ rDNA (Fig. 2c) probe revealed two fragments for each single and double digestion, except for EagI/BssHII. This suggests the presence of two rrn operons in the strain FD92 chromosome. The strong signal observed in lane 6 (Fig. 2c) for EagI/SalI digestion corresponds to a doublet of 14 and $15 \mathrm{kbp}$. The $16 \mathrm{~S}$ rDNA probe also hybridized with control DNA from healthy plants (lanes 12 and 13), but the sizes of the revealed fragments were different from those of the infected plant DNA digested with the same enzymes. This might be due to non-specific hybridization of broad bean chloroplast rDNA. As no fragment was revealed after the hybridization for the EagI/BssHII double digestion (lane 8) and as small fragments could possibly have run out of the 


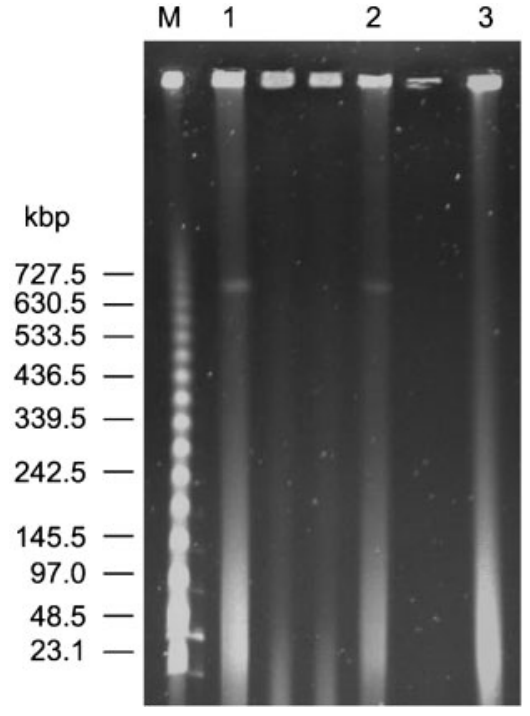

Fig. 1. PFGE of DNA prepared from FD-P-infected broad beans (lanes 1 and 2) and healthy broad beans (lane 3). M, low-sizerange PFGE marker (kbp).

gel, a Southern blotting experiment was carried out after conventional agarose gel electrophoresis. As expected, two small fragments of 3.5 and $3.8 \mathrm{kbp}$ were revealed when DNA from FD92-infected broad bean was digested by EagI/ BssHII and hybridized with the $16 \mathrm{~S}$ rDNA probe (Fig. 2i, lane 5).

\section{Estimation of the size of the strain FD92 chromosome}

The size of the chromosome of strain FD92 was estimated to be $671 \pm 14 \mathrm{kbp}$. This represents the mean of the sums of the size of all fragments generated by single digestions with BssHII, EagI and MluI enzymes and double digestion with $M l u \mathrm{I} / B s s \mathrm{HII}$ for which every fragment was directly visible on PFGE gels and hybridization patterns.

\section{Mapping of the strain FD92 chromosome}

Data from all independent single or double restrictions and from hybridization profiles were assembled to derive a restriction map for the strain FD92 chromosome, showing locations of the different genetic markers (Fig. 3). Thirteen restriction sites and nine genetic markers located on six restriction fragments were mapped on the chromosome. The FDDH29 marker and tuf gene were positioned on one Sall restriction fragment of $35.6 \pm 2.7 \mathrm{kbp}$. The map gene and FD2 marker were located on one EagI/SalI restriction fragment of $211.1 \pm 4.3 \mathrm{kbp}$. The $\sec Y$ gene, already known from sequence data to be located next to the map gene (Arnaud et al., 2007; Arnaud, 2006), also mapped to this restriction fragment. The FDSH05 marker and $u v r B-\operatorname{degV}$ genes were positioned on one EagI fragment of $146.6 \pm 6.5 \mathrm{kbp}$ and on one SalI/MluI fragment of $91.9 \pm 5.7 \mathrm{kbp}$, respectively. Genome walking, performed using the $16 \mathrm{~S}$ rDNA sequence present in databases (accession number X76560) (Seemüller et al., 1994) confirmed the presence of two copies of the $r r n$ operon on the FD-P chromosome (Arnaud, 2006). They were located on two EagI/BssHII restriction fragments of 3.5 and $3.8 \mathrm{kbp}$. The presence of a BssHII site at the beginning of both 16S rDNA sequences enabled the operons to be orientated. With the exception of the 16S rDNA gene, none of the known FD-P sequences contained a restriction site used to build up the map and no genetic marker could therefore be precisely positioned on the chromosome. For the SalI single digestion and MluI/SalI, MluI/EagI, BssHII/SalI, BssHII/EagI and EagI/SalI double digestions, some fragments smaller than $28 \mathrm{kbp}$, presented in italics in Table 3 (column 3), were not distinguished by either PFGE profiles or hybridization patterns, but instead were deduced from mapping. The size of the smaller restriction fragment was estimated to be $3.5 \mathrm{kbp}$ and the larger, with no mapped internal sites, was estimated to be $211 \mathrm{kbp}$.

No restriction enzyme was found to cut the chromosome once to give a linear molecule; consequently, the Bss HII restriction site on the first copy of the $16 \mathrm{~S}$ rDNA was arbitrarily chosen as the beginning of the map.

\section{DISCUSSION}

The recent sequencing of $12 \mathrm{kbp}$ of the FD-P genetic rplCinfA locus, encompassing the secY-map locus, revealed that this fragment has a G $+\mathrm{C}$ content of $27 \mathrm{~mol} \%$ (Arnaud, 2006). This locus is highly conserved in most microbial genomes and its $\mathrm{G}+\mathrm{C}$ content is linearly correlated with the $\mathrm{G}+\mathrm{C}$ content of the whole genome. This permitted us to estimate the $\mathrm{G}+\mathrm{C}$ content of the FD-P genome as being close to 22-23 mol\% (Arnaud, 2006). According to this result, one can estimate the theoretical frequency of the different restriction sites for the enzymes used in this study. EagI (CGGCCG) and BssHII (GCGCGC) should cut the genome with a frequency of $(0.115)^{6}=1 / 430000 \mathrm{bp}$, i.e. one to two times. The observed frequency was a little higher, with four sites for the enzyme EagI and two for BssHII. This can be explained by the fact that these sites were mainly located in the vicinity of the $r r n$ operons which are known to have a higher $\mathrm{G}+\mathrm{C}$ content $-47 \mathrm{~mol} \%$ in the case of the FD-P 16S rDNA, as is the case for other mollicute genomes (Barré et al., 2004; Razin et al., 1998; Sirand-Pugnet et al., 2007). The concentration of $\mathrm{G}+\mathrm{C}$-rich restriction sites in the vicinity of the $\mathrm{rrn}$ operons has also been observed on physical maps of Mycoplasma hominis (Ladefoged \& Christiansen, 1992) and Spiroplasma citri strains (Ye et al., 1992).

The theoretical frequency of MluI (ACGCGT) and SalI (GTCGAC) restriction sites should be $(0.115)^{4} \times$ 

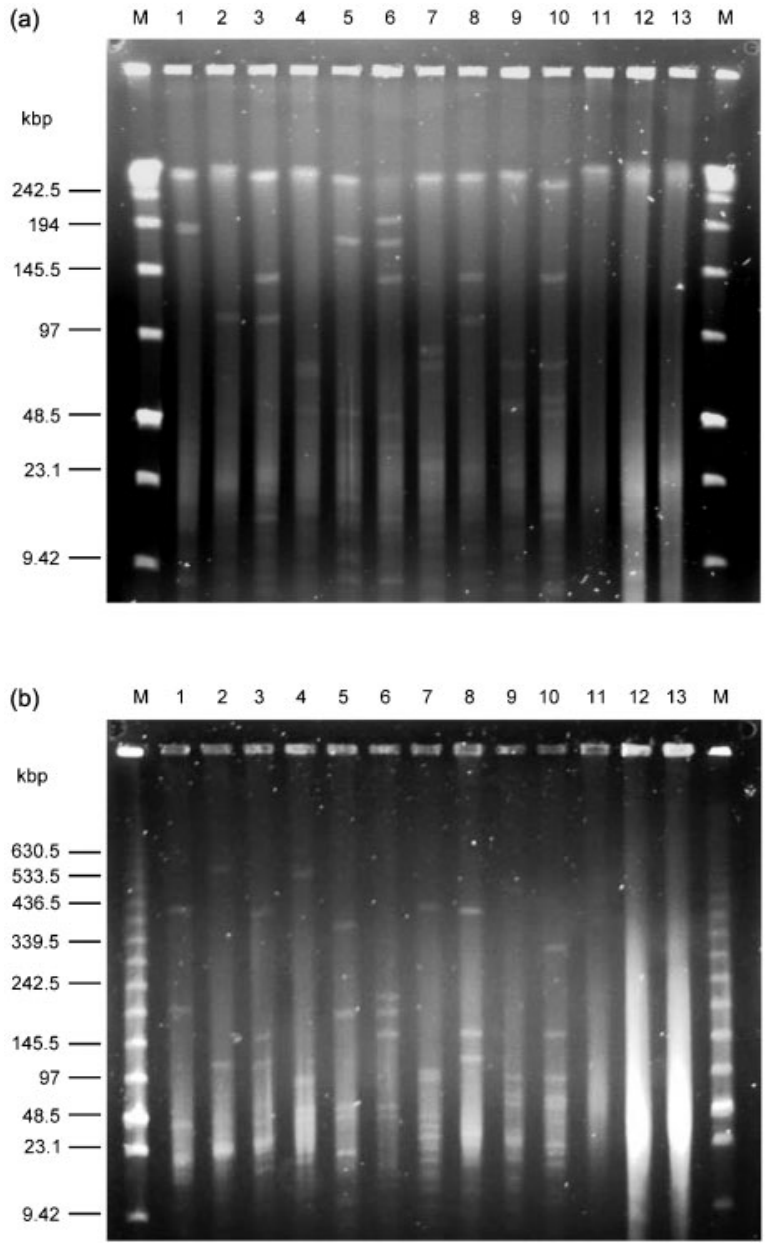

(c)

(c)

(d)

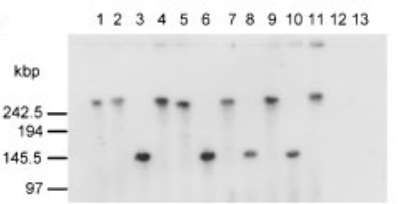

(e)

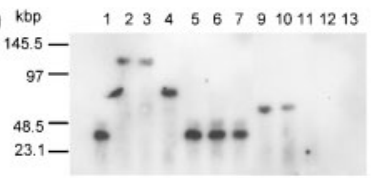

(f)

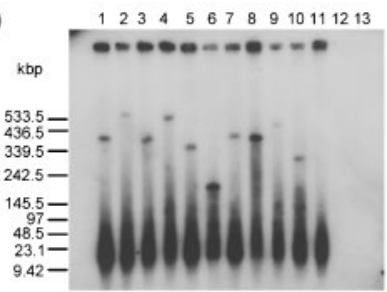

(g)
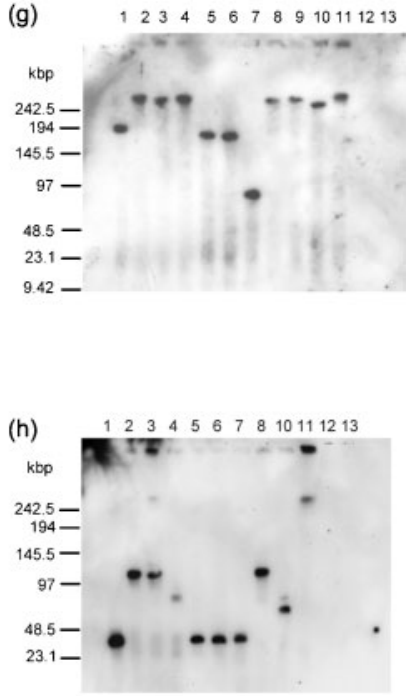

(i)

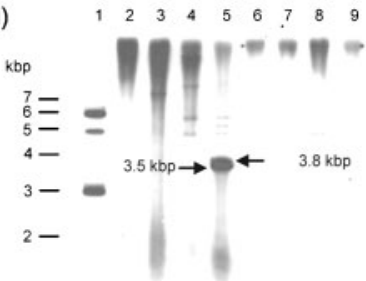

Fig. 2. (a, b) PFGE of DNA prepared from FD-P-infected (lanes 1-11) and healthy (lanes 12-13) broad beans, single- or double-digested with various rare-cutting enzymes. Conditions of electrophoresis were adapted for resolution of low- (a) or medium- (b) size-range DNA. Lanes: 1, Sall; 2, BssHII; 3, Eagl; 4, Mlul; 5, BssHII/Sall; 6, Eagl/Sall; 7, Mlul/Sall; 8, Eagl/BssHII; 9, Mlul/BssHII; 10, Mlul/Eagl; 11, undigested; 12, Sall; 13, BssHII; M, low-size-range PFGE marker (kbp). (c-h) Southern blot hybridization profiles of low-size-range PFGE gels probed with 16S rDNA (c), FDSH05 (d), FDDH29 or tuf (e, h), uvrB-degV (g) and medium-size-range PFGE gels probed with map (f). (i) Southern blot hybridization of a conventional electrophoresis gel probed with 16S rDNA. Lanes 1, recombinant pGEM-T Easy with 16S rDNA insert; 2-5, DNA from FD-infected broad beans, undigested (2) or digested with BssHII (3), Eagl (4), BssHII and Eagl (5); 6-9, DNA from healthy broad beans, undigested (6) or digested with BssHII (7), Eagl (8), BssHII and Eagl (9).

$(0.39)^{2}=1 / 37600 \mathrm{bp}$, i.e. 18 sites on the FD-P genome. However, MluI and SalI sites were found only three and four times, respectively. Such a discrepancy between the theoretical and observed frequency has also been found for $S$. citri where the SalI restriction sites were 10 times underrepresented on its physical map (Ye et al., 1992). In addition, the Mycoplasma mycoides subsp. mycoides $\mathrm{Y}$ and $M$. hominis physical maps showed frequencies of restriction sites containing one A and one T (BamHI, KpnI, SalI and XhoI) six to ten times lower than the theoretical ones (Ladefoged \& Christiansen, 1992; Pyle \& Finch, 1988). This phenomenon could be due to methylation of the majority of these restriction sites. However, our analyses performed in silico on the sequenced genome of different mollicutes, using the MolliGen database (Barré et al., 2004) and pDRAW32 software, showed that frequencies of SalI and $M l u I$ sites are also under-represented. For example, in the Mycoplasma capricolum genome (Wise et al., 2006) (accession number NC_007633, 23.77 mol\% G+C), only two MluI sites and no SalI sites were found, despite the 31 theoretically calculated. In addition, the M. mycoides genome (Westberg et al., 2004) (NC_005364.2, $23.96 \mathrm{~mol} \% \mathrm{G}+\mathrm{C}$ ) presented only six MluI sites instead of 37. So, another explanation could be that the di- or trinucleotides that make up these sites could be underrepresented in these genomes. This can be explained because small genomes of mollicutes have a high proportion of coding sequences, ranging from $73 \%$ for 
Table 3. Number, mean sizes and probe hybridization of fragments obtained by single and double digestions of the FD-P chromosome

\begin{tabular}{|c|c|c|c|c|}
\hline Enzyme & Fragment name & Mean size $\pm \mathrm{SD}^{\star}(\mathbf{k b p})$ & Hybridizing probes & Sum of mean sizes $(\mathrm{kbp}) \dagger$ \\
\hline \multirow[t]{2}{*}{$B s s \mathrm{HII}$} & A & $552.1 \pm 8.4$ & map, secY, uvrB-degV, FD2, FDSH05, 16S rDNA & \\
\hline & $\mathrm{B}$ & $110.2 \pm 2.7$ & FDDH29, tuf & 662.3 \\
\hline \multirow[t]{4}{*}{ EagI } & A & $404.9 \pm 5.1$ & map, uvrB- $\operatorname{deg} V$, FD2 $\ddagger$ & \\
\hline & $\mathrm{B}$ & $146.6 \pm 6.5$ & FDSH05 & \\
\hline & $\mathrm{C}$ & $109 \pm 3.1$ & 16S rDNA, FDDH29, tuf & \\
\hline & $\mathrm{D}$ & 14 & $16 \mathrm{~S}$ rDNA & 673.4 \\
\hline \multirow[t]{3}{*}{ MluI } & A & $515.6 \pm 6.4$ & map, secY, uvrB- $\operatorname{deg} V$, FD2, FDSH05, 16S rDNA & \\
\hline & $\mathrm{B}$ & $80.1 \pm 6.6$ & FDDH29, tuf & \\
\hline & $\mathrm{C}$ & $73.2 \pm 6.2$ & & 668.9 \\
\hline \multirow[t]{4}{*}{ SalI } & A & $415.1 \pm 8.2$ & map, secY, FD2, FDSH05, 16S rDNA & \\
\hline & $\mathrm{B}$ & $193 \pm 6.4$ & uvrB- $\operatorname{deg} V, 16 \mathrm{~S}$ rDNA & \\
\hline & $\mathrm{C}$ & $35.6 \pm 2.7$ & FDDH29, tuf & \\
\hline & $\mathrm{D} \$$ & 27.5 & & 671.2 \\
\hline \multirow[t]{6}{*}{ BssHII/SalI } & A & $365.7 \pm 5.4$ & map, secY, FD2, FDSH05 & \\
\hline & $\mathrm{B}$ & $181.2 \pm 3.9$ & $16 \mathrm{~S}$ rDNA, uvrB- $\operatorname{deg} V$ & \\
\hline & $\mathrm{C}$ & $53 \pm 2.8$ & $16 \mathrm{~S}$ rDNA & \\
\hline & $\mathrm{D}$ & $38.2 \pm 7.4$ & FDDH29, tuf & \\
\hline & $\mathrm{E} \$$ & 27.5 & & \\
\hline & F\$ & 8 & & 673.5 \\
\hline \multirow[t]{8}{*}{ EagI/SalI } & A & $211.1 \pm 4.3$ & map, FD2末 & \\
\hline & $\mathrm{B}$ & $180.9 \pm 6.4$ & $u v r B-\operatorname{deg} V$ & \\
\hline & $\mathrm{C}$ & $146.2 \pm 5.6$ & FDSH05 & \\
\hline & $\mathrm{D}$ & $52 \pm 2.6$ & & \\
\hline & $\mathrm{E}$ & $38.9 \pm 5.8$ & FDDH29, tuf & \\
\hline & F\$ & 27.5 & & \\
\hline & G & 14 & $16 \mathrm{~S}$ rDNA & \\
\hline & $\mathrm{H}$ & 13 & $16 \mathrm{~S}$ rDNA & 683.6 \\
\hline \multirow[t]{7}{*}{ MluI/SalI } & A & $418.1 \pm 5.2$ & map, secY, FD2, FDSH05, 16S rDNA & \\
\hline & $\mathrm{B}$ & $91.9 \pm 5.7$ & $u v r B-\operatorname{deg} V$ & \\
\hline & $\mathrm{C}$ & $81.8 \pm 6.4$ & & \\
\hline & $\mathrm{D}$ & $38.6 \pm 8.2$ & FDDH29, tuf & \\
\hline & $\mathrm{E}$ & 26 & $16 \mathrm{~S}$ rDNA & \\
\hline & $\mathrm{F} \$$ & 11 & & \\
\hline & G\$ & 16 & & 683.3 \\
\hline \multirow[t]{6}{*}{$\mathrm{EagI} / \mathrm{BssHII}$} & A & $398 \pm 10.2$ & map, uvrB- $\operatorname{deg} V, \mathrm{FD} 2 \ddagger$ & \\
\hline & $\mathrm{B}$ & $146.9 \pm 6.2$ & FDSH05 & \\
\hline & $\mathrm{C}$ & $110.5 \pm 4.3$ & FDDH29, tuf & \\
\hline & $\mathrm{D} \$$ & 9 & & \\
\hline & $\mathrm{E}$ & 3.8 & $16 \mathrm{~S}$ rDNA & \\
\hline & $\mathrm{F}$ & 3.5 & $16 \mathrm{~S}$ rDNA & 671.6 \\
\hline \multirow[t]{5}{*}{ MluI/BssHII } & A & $465 \pm 11.6$ & map, secY, uvrB-degV, FD2, FDSH05 & \\
\hline & $\mathrm{B}$ & $80.7 \pm 7.6$ & & \\
\hline & $\mathrm{C}$ & $59.1 \pm 4$ & FDDH29, tuf & \\
\hline & $\mathrm{D}$ & $52.7 \pm 3.4$ & $16 \mathrm{~S}$ rDNA & \\
\hline & $\mathrm{E}$ & 18 & $16 \mathrm{~S}$ rDNA & 675.5 \\
\hline \multirow[t]{7}{*}{ MluI/EagI } & A & $313.3 \pm 7.9$ & map, uvrB- $\operatorname{deg} V, \mathrm{FD} 2 \ddagger$ & \\
\hline & B & $145.5 \pm 4.6$ & FDSH05 & \\
\hline & $\mathrm{C}$ & $82 \pm 6$ & & \\
\hline & $\mathrm{D}$ & $58.7 \pm 3.6$ & 16S rDNA, FDDH29, tuf & \\
\hline & $\mathrm{E}$ & $50.7 \pm 2.5$ & & \\
\hline & $\mathrm{F}$ & $21 \pm 1$ & $16 \mathrm{~S}$ rDNA & \\
\hline & G\$ & 15 & & 686.2 \\
\hline
\end{tabular}

${ }^{*}$ Means were calculated from at least three separate PFGE experiments. Italic numbers indicate fragments smaller than $28 \mathrm{kbp}$ that were not distinguished by either PFGE profiles or hybridization patterns, but instead were deduced from mapping.

$\dagger$ Sums of the mean sizes of the different restriction fragments generated.

\$ybridization not demonstrated for $\sec Y$.

§Fragment not observed on PFGE gels for which the theoretical size was deduced by placing the restriction sites on the $671 \mathrm{kbp}$ genome map. 


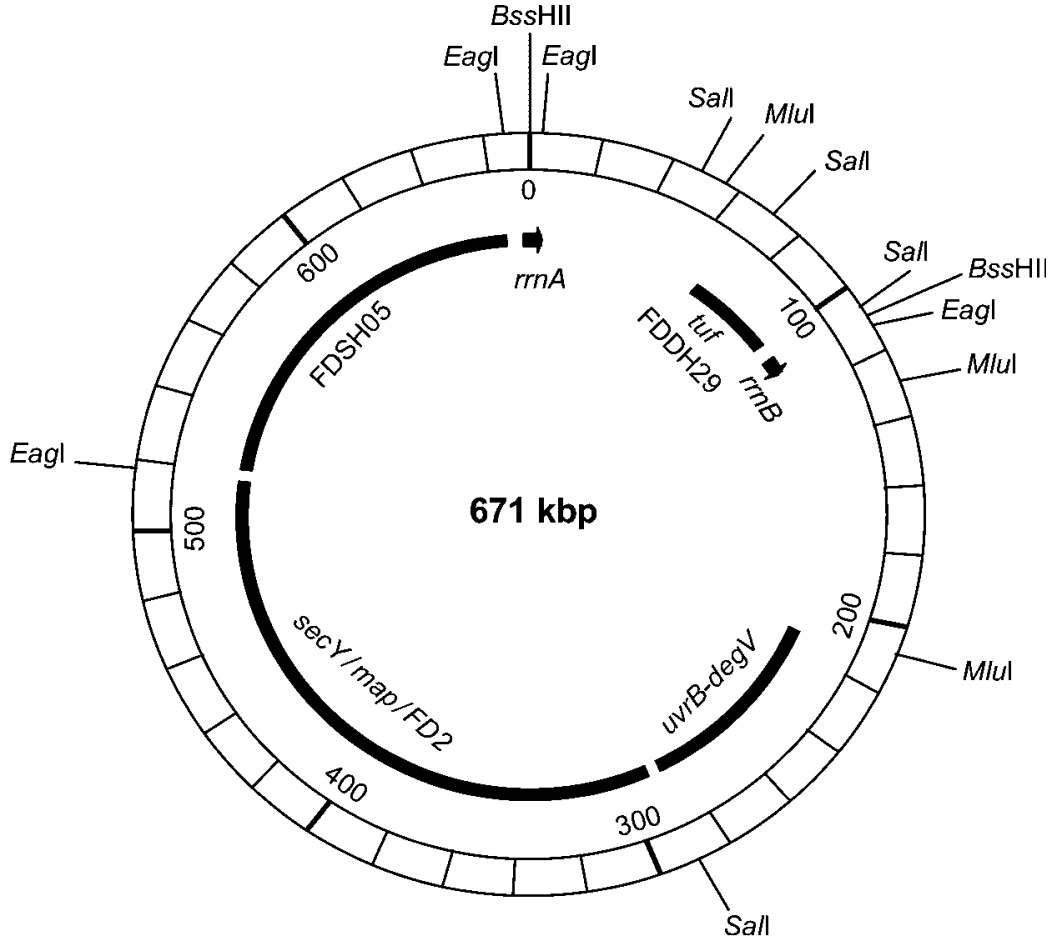

Fig. 3. Physical and genetic map of the chromosome of the FD-P. Restriction sites for BssHII, Eagl, Mlul and Sall are indicated on the circular scale. Restriction fragments hybridizing with 16S rDNA, tuf, FDDH29, uvrB-degV, secY, map, FD2 and FDSH05 probes are delimited by bars. The orientation of $r r n$ genes is symbolized by arrows.
'Candidatus P. asteris' to $92 \%$ for Mesoplasma florum, according to MolliGen (Barré et al., 2004), in which nucleotide distribution is not random, but is determined by codon usage bias. As an example, our analyses showed that the ACG trinucleotide of the MluI site, which should theoretically appear 5233 times in the M. capricolum genome, was only found 97 times. In addition, the CGT trinucleotide of MluI was found at only 908 instead of 5233 positions, whereas the GCT trinucleotide with the same theoretical frequency appeared 8141 times.

Only four of the 10 restriction enzymes assayed (Bss HII, EagI, MluI and SalI) produced fragments that could be used for mapping the strain FD92 chromosome. They revealed 13 restriction sites of which 10 were concentrated in a $140 \mathrm{kbp}$ region, suggesting a heterogeneous repetition of di- and trinucleotides that make up their cutting sites on the phytoplasma chromosome. Similar results have been observed on 120-200 kbp of the chromosome maps of $S$. citri (Ye et al., 1992), 'Candidatus P. mali' (Lauer \& Seemüller, 2000), 'Candidatus P. prunorum' (Marcone \& Seemüller, 2001) and Mycoplasma pneumoniae (Krause \& Mawn, 1990).

The two copies of the rrn operon were shown to have the same orientation and to be $100 \mathrm{kbp}$ apart on the FD-P chromosome, with the tuf gene lying about $30 \mathrm{kbp}$ upstream from $r r n B$. Our analyses, performed with the MolliGen database (Barré et al., 2004), revealed a similar arrangement in the genomes of aster yellows witches' broom phytoplasma (Bai et al., 2006; Oshima et al., 2004) and Mycoplasma synoviae (Vasconcelos et al., 2005). The $r r n B$ operon had an opposite orientation in the genomes of sweet potato little leaf and onion yellows phytoplasmas (Oshima et al., 2004; Padovan et al., 2000). The sec $Y$ and map genes were found to be adjacent on the FD-P chromosome. They make up part of the $12 \mathrm{kbp} r p l C$-infA locus characterized by Arnaud (2006) which also contains genes encoding ribosomal proteins and translation initiation factor 1 (infA). This gene cluster is well conserved among mollicutes, except in Mycoplasma gallisepticum and Mycoplasma synoviae where it has been divided by chromosomal rearrangements (Sirand-Pugnet et al., 2007). In the rplC-infA locus of all sequenced mollicutes, the $\sec Y$ and map genes are not adjacent, but are always separated by the $a d k$ gene which encodes an adenylate kinase.

The size of the strain FD92 chromosome was estimated to be $671 \mathrm{kbp}$. This is in accordance with the chromosome size of phytoplasmas from the $16 \mathrm{SrV}$ phylogenetic group determined by Marcone et al. (1999) which ranges from $680 \mathrm{kbp}$ for 'Candidatus Phytoplasma ulmi' strain ULW to $820 \mathrm{kbp}$ for Rubus stunt phytoplasma. Chromosome size is not related to phylogenetic relationships in this group since FD-P is phylogenetically closer to alder yellows phytoplasma (strain Aly), which has a chromosome size of $750 \mathrm{kbp}$, than to ULW, with a chromosome of $680 \mathrm{kbp}$ (Angelini et al., 2003; Arnaud et al., 2007; Lee et al., 2004b). The absence of a correlation between the genome size of mollicutes and their phylogenetic position has been described (Marcone et al., 1999; Neimark \& Kirkpatrick, 1993; Sirand-Pugnet et al., 2007).

In conclusion, 13 restriction sites and nine genetic markers located on six restriction fragments were mapped on the $671 \mathrm{kbp}$ chromosome of the FD92 epidemic strain of FD- 
P. This physical and genetic map will be useful for the assembly steps of the genome sequencing project which is underway for this strain. Furthermore, it will be interesting to compare this map with those of other FD-P strains which present different biological properties to strain FD92 in terms of interaction with hosts, colonization and/or multiplication. In addition, this will add new data to the growing body of sequenced data for comparative genomic studies among phytoplasmas and mollicutes.

\section{ACKNOWLEDGEMENTS}

This work was started during the postdoctoral stay of Fiona Constable, funded by the Conseil Régional de Bourgogne. We thank our colleagues Bernard Alixant, Denis Clair, Jean-Luc Danet and François Ferrer for maintaining phytoplasma-infected plants and insects. We are grateful to Delphine Desqué, Virginie Machefer, JeanLuc Danet and Pascal Salar for their help in purifying phytoplasma DNA. We are indebted to Dr Laurent Pichon for his hospitality in University of Burgundy on the PFGE device and other facilities. This research was funded by the Conseil Régional de Bourgogne, the Bureau Interprofessionnel des Vins de Bourgogne and the Conseil Interprofessionnel du Vin de Bordeaux.

\section{REFERENCES}

Angelini, E., Clair, D., Borgo, M., Bertaccini, A. \& Boudon-Padieu, E. (2001). Flavescence dorée in France and Italy - occurrence of closely related phytoplasma isolates and their near relationships to Palatinate grapevine yellows and an alder yellows phytoplasma. Vitis 40, 79-86.

Angelini, E., Negrisolo, E., Clair, D., Borgo, M. \& Boudon-Padieu, E. (2003). Phylogenetic relationships among Flavescence dorée strains and related phytoplasmas determined by heteroduplex mobility assay and sequence of ribosomal and nonribosomal DNA. Plant Pathol 52, 663-672.

Arnaud, G. (2006). Diversité génétique du phytoplasme de la Flavescence dorée de la vigne et des phytoplasmes apparentés: variabilité des loci secY-map et uvrB-degV. PhD thesis, University Victor Ségalen Bordeaux 2, France.

Arnaud, G., Malembic-Maher, S., Salar, P., Bonnet, P., Maixner, M., Marcone, C., Boudon-Padieu, E. \& Foissac, X. (2007). Multilocus sequence typing confirms the close genetic inter-relatedness between three distinct flavescence dorée phytoplasma strain clusters and group $16 \mathrm{SrV}$ phytoplasmas infecting grapevine and alder in Europe. Appl Environ Microbiol 73, 4001-4010.

Bai, X., Zhang, J., Ewing, A., Miller, S. A., Jancso Radek, A., Shevchenko, D. V., Tsukerman, K., Walunas, T., Lapidus, A. \& other authors (2006). Living with genome instability: the adaptation of phytoplasmas to diverse environments of their insect and plant hosts. J Bacteriol 188, 3682-3696.

Barré, A., de Daruvar, A. \& Blanchard, A. (2004). MolliGen, a database dedicated to the comparative genomics of Mollicutes. Nucleic Acids Res 32, D307-D310.

Boudon-Padieu, E. (2002). Flavescence dorée of the grapevine: knowledge and new developments in epidemiology, etiology and diagnosis. Atti Giornate Fitopatol 1, 15-34.

Caudwell, A., Kuszala, C., Bachelier, J. C. \& Larrue, J. (1970). Transmission de la Flavescence dorée de la vigne aux plantes herbacées par l'allongement du temps d'utilisation de la cicadelle Scaphoideus littoralis Ball et l'étude de sa survie sur un grand nombre d'espèces végétales. Ann Phytopathol 2, 415-428.
Caudwell, A., Kuszala, C., Larrue, J. \& Bachelier, J. C. (1972). Transmission de la Flavescence dorée de la fève à la fève par des cicadelles des genres Euscelis et Euscelidius. Intervention possible de ces insectes dans l'épidémiologie du Bois noir en Bourgogne. Ann Phytopathol, 181-189.

Caudwell, A., Kuszala, C. \& Larrue, J. (1973). Techniques utilisables pour l'étude de la Flavescence dorée de la vigne. Riv Patol Veg 9, 269-276.

Christensen, N. M., Axelsen, K. B., Nicolaisen, M. \& Schulz, A. (2005). Phytoplasmas and their interactions with hosts. Trends Plant Sci 10, 526-535.

Cimerman, A., Arnaud, G. \& Foissac, X. (2006). Stolbur phytoplasma genome survey achieved using a suppression subtractive hybridization approach with high specificity. Appl Environ Microbiol 72, 3274-3283.

Clair, D., Larrue, J., Aubert, G., Gillet, J., Cloquemin, G. \& BoudonPadieu, E. (2003). A multiplex nested-PCR assay for sensitive and simultaneous detection and direct identification of phytoplasma in the elm yellows group and stolbur group and its use in survey of grapevine yellows in France. Vitis 42, 151-157.

Daire, X., Boudon-Padieu, E., Berville, A., Schneider, B. \& Caudwell, A. (1992). Cloned DNA probes for detection of grapevine flavescence dorée mycoplasma-like organism (MLO). Ann Appl Biol 121, 95-103.

Daire, X., Clair, D., Reinert, W. \& Boudon-Padieu, E. (1997). Detection and differentiation of grapevine yellows phytoplasmas belonging to the elm yellows group and to the stolbur subgroup by PCR amplification of non-ribosomal DNA. Eur J Plant Pathol 103, 507-514.

Deng, S. J. \& Hiruki, C. (1991). Amplification of 16 S ribosomal-RNA genes from culturable and nonculturable mollicutes. J Microbiol Methods 14, 53-61.

Firrao, G., Smart, C. D. \& Kirkpatrick, B. C. (1996). Physical map of the western X-disease phytoplasma chromosome. J Bacteriol 178, 3985-3988.

IRPCM Phytoplasma/Spiroplasma Working Team - Phytoplasma taxonomy group (2004). 'Candidatus Phytoplasma', a taxon for the wall-less, non-helical prokaryotes that colonize plant phloem and insects. Int J Syst Evol Microbiol 54, 1243-1255.

Krause, D. C. \& Mawn, C. B. (1990). Physical analysis and mapping of the Mycoplasma pneumoniae chromosome. J Bacteriol 172, $4790-4797$.

Ladefoged, S. A. \& Christiansen, G. (1992). Physical and genetic mapping of the genomes of five Mycoplasma hominis strains by pulsed-field gel electrophoresis. J Bacteriol 174, 2199-2207.

Lauer, U. \& Seemüller, E. (2000). Physical map of the chromosome of the apple proliferation phytoplasma. J Bacteriol 182, 1415-1418.

Lee, I. M., Davis, R. E. \& Gundersen-Rindal, D. E. (2000). Phytoplasma: phytopathogenic mollicutes. Annu Rev Microbiol 54, 221-255.

Lee, I. M., Gundersen-Rindal, D. E., Davis, R. E., Bottner, K. D., Marcone, C. \& Seemüller, E. (2004a). 'Candidatus Phytoplasma asteris', a novel phytoplasma taxon associated with aster yellows and related diseases. Int J Syst Evol Microbiol 54, 1037-1048.

Lee, I. M., Martini, M., Marcone, C. \& Zhu, S. F. (2004b). Classification of phytoplasma strains in the elm yellows group (16SrV) and proposal of 'Candidatus Phytoplasma ulmi' for the phytoplasma associated with elm yellows. Int J Syst Evol Microbiol 54, 337-347.

Liefting, L. W. \& Kirkpatrick, B. C. (2003). Cosmid cloning and sample sequencing of the genome of the uncultivable mollicute, Western Xdisease phytoplasma, using DNA purified by pulsed-field gel electrophoresis. FEMS Microbiol Lett 221, 203-211.

Lorenz, K. H., Schneider, B., Ahrens, U. \& Seemüller, E. (1995). Detection of the apple proliferation and pear decline phytoplasmas 
by PCR amplification of ribosomal and nonribosomal DNA. Phytopathology 85, 771-776.

Maixner, M., Ahrens, U. \& Seemüller, E. (1995). Detection of the German grapevine yellows (Vergilbungskrankheit) MLO in grapevine, alternative hosts and a vector by a specific PCR procedure. Eur J Plant Pathol 101, 241-250.

Marcone, C. \& Seemüller, E. (2001). A chromosome map of the European stone fruit yellows phytoplasma. Microbiology 147, 1213-1221.

Marcone, C., Neimark, H. C., Ragozzino, A., Lauer, U. \& Seemüller, E. (1999). Chromosome sizes of phytoplasmas composing major phylogenetic groups and subgroups. Phytopathology 89, 805-810.

Neimark, H. \& Kirkpatrick, B. C. (1993). Isolation and characterization of full-length chromosomes from non-culturable plant-pathogenic mycoplasma like organisms. Mol Microbiol 7, 21-28.

Oshima, K., Kakizawa, S., Nishigawa, H., Jung, H. Y., Wei, W., Suzuki, S., Arashida, R., Nakata, D., Miyata, S. \& other authors (2004). Reductive evolution suggested from the complete genome sequence of a plantpathogenic phytoplasma. Nat Genet 36, 27-29.

Padovan, A. C., Firrao, G., Schneider, B. \& Gibb, K. S. (2000). Chromosome mapping of the sweet potato little leaf phytoplasma reveals genome heterogeneity within the phytoplasmas. Microbiology 146, 893-902.

Pyle, L. E. \& Finch, L. R. (1988). A physical map of the genome of Mycoplasma mycoides subspecies mycoides $\mathrm{Y}$ with some functional loci. Nucleic Acids Res 16, 6027-6039.

Razin, S., Yogev, D. \& Naot, Y. (1998). Molecular biology and pathogenicity of mycoplasmas. Microbiol Mol Biol Rev 62 , 1094-1156.

Sambrook, J., Fritsch, E. F. \& Maniatis, T. (1989). Molecular Cloning: A Laboratory Manual, 2nd edn. Cold Spring Harbor, NY: Cold Spring Harbor Laboratory Press.

Seemüller, E., Schneider, B., Mäurer, R., Ahrens, U., Daire, X., Kison, H., Lorenz, K. H., Firrao, G., Avinent, L. \& other authors (1994). Phylogenetic classification of phytopathogenic mollicutes by sequence analysis of 16S ribosomal DNA. Int J Syst Bacteriol 44, 440-446.

Seemüller, E., Garnier, M. \& Schneider, B. (2002). Mycoplasmas of plants and insects. In Molecular Biology and Pathogenicity of
Mycoplasmas, pp. 91-115. Edited by S. R. R. Herrmann. New York: Kluwer Academic/Plenum Publishers.

Sirand-Pugnet, P., Citti, C., Barre, A. \& Blanchard, A. (2007). Evolution of mollicutes: down a bumpy road with twists and turns. Res Microbiol 158, 754-766.

Smart, C. D., Schneider, B., Blomquist, C. L., Guerra, L. J., Harrison, N. A., Ahrens, U., Lorenz, K. H., Seemüller, E. \& Kirkpatrick, B. C. (1996). Phytoplasma-specific PCR primers based on sequences of the 16S-23S rRNA spacer region. Appl Environ Microbiol 62, 2988-2993.

Vasconcelos, A. T. R., Ferreira, H. B., Bizarro, C. V., Bonatto, S. L., Carvalho, M. O., Pinto, P. M., Almeida, D. F., Almeida, L. G. P., Almeida, R. \& other authors (2005). Swine and poultry pathogens: the complete genome sequences of two strains of Mycoplasma hyopneumoniae and a strain of Mycoplasma synoviae. J Bacteriol 187, 5568-5577.

Weintraub, P. G. \& Beanland, L. (2006). Insect vectors of phytoplasmas. Annu Rev Entomol 51, 91-111.

Weisburg, W. G., Tully, J. G., Rose, D. L., Petzel, J. P., Oyaizu, H., Yang, D., Mandelco, L., Sechrest, J., Lawrence, T. G. \& other authors (1989). A phylogenetic analysis of the mycoplasmas: basis for their classification. J Bacteriol 171, 6455-6467.

Westberg, J., Persson, A., Holmberg, A., Goesmann, A., Lundeberg, J., Johansson, K. E., Pettersson, B. \& Uhlen, M. (2004). The genome sequence of Mycoplasma mycoides subsp mycoides SC type strain PG1(T), the causative agent of contagious bovine pleuropneumonia (CBPP). Genome Res 14, 221-227.

Wise, K. S., Foecking, M. F., Roske, K., Lee, Y. J., Lee, Y. M., Madan, A. \& Calcutt, M. J. (2006). Distinctive repertoire of contingency genes conferring mutation-based phase variation and combinatorial expression of surface lipoproteins in Mycoplasma capricolum subsp. capricolum of the Mycoplasma mycoides phylogenetic cluster. J Bacteriol 188, 4926-4941.

Ye, F., Laigret, F., Whitley, J. C., Citti, C., Finch, L. R., Carle, P., Renaudin, J. \& Bové, J. M. (1992). A physical and genetic map of the Spiroplasma citri genome. Nucleic Acids Res 20, 1559-1565.

Edited by: G. Firrao 